\title{
Response of Some Sugar Beet (Beta vulgaris L.) Cultivars to Organic Manure and Mineral Fertilizers under Sandy Calcareous Soil Condition at South Sinai- Egypt
}

\author{
Habib, A.A.M. ${ }^{1}$
}

\begin{abstract}
This study was conducted during two successive seasons $(2018 / 2019$ and $2019 / 2020)$ to study the effect of different rates of organic manure $\left(0,10,20 \mathrm{~m}^{3} \mathrm{ha}^{-1}\right)$ and different rates of mineral nitrogen (142 and $\left.285 \mathrm{~kg} \mathrm{~N} \mathrm{ha}^{-1}\right)$ on four species of sugar beet cultivars, i.e., Casiopia $\left(\mathrm{T}_{1}\right)$, Salama $\left(T_{2}\right)$, Sahar $\left(T_{3}\right)$ and Faten $\left(T_{4}\right)$. The quality and nutrient contents of the four sugar beet species which grown in sandy calcareous soil. The design of experiment is split-split plots, where the main plots were assigned to 3 rates of organic manure, 2 levels of $\mathbf{N}$ fertilizer as the subplots and 4 cultivars of sugar beet were arranged to random as sub-sub plots. The results showed the highest yield of roots and top fresh weight (69.8 and 19.8 ton ha-1) was obtained under addition $20 \mathrm{~m}^{3} \mathrm{ha}^{-1}$ organic manure + $285 \mathrm{~kg} \mathrm{~N} \mathrm{ha}^{-1}$ with Salama and/or Faten cultivars in the means of $1^{\text {st }}$ and $2^{\text {nd }}$ seasons. Also, the highest $N, P, K$ uptake and sucrose yield of roots was obtained under fertilization with $\left(20 \mathrm{~m}^{3}\right.$ organic manure $+285 \mathrm{~kg} \mathrm{~N} \mathrm{ha}^{-1}$ with Salama cultivar). While the highest $P$ and $K$ uptake of foliage was obtained with $\left(20 \mathrm{~m}^{3}\right.$ organic manure $+285 \mathrm{~kg}$ $\mathrm{N} \mathrm{ha}^{-1}+$ Faten and/or Sahar cultivars). Also, data showed that studied treatments improve some soil properties and increase soil content of available $N, P$ and $K$ nutrients. Increasing of organic matter and decrease $\mathrm{CaCO}_{3} \%$ with increasing organic manure application, while increasing application of $\mathrm{N}$ lead to a slight effect on both $\mathrm{CaCO}_{3}(\%)$ and organic matter content. Since saline water has been proposed as an alternative irrigation source for sugar beet, attention should be focused on its positive and negative effects on quality and quantity of sugar beet.
\end{abstract}

Key Words: Cultivars of sugar beet; Organic manure, mineral N fertilizers; Sandy calcareous soil; Sugar yield and Sucrose yield.

\section{INTRODUCTION}

Sugar beet (Beta vulgaris L.) is one of the main sugar crops in the world which has importance to fulfill the requirement of market for sugar supply scarcity. The developed countries found alternative crops over than sugar cane, and also had cultivation to the production of sugar from it, to accomplish public requirement and to improve the country economy by export. The total world production of sugar beet is 238.8 million tones, with a total area 5.83 million hectare, with an average yield 40.84 t. ha ${ }^{-1}$, (FAO, 2012). Further, sugar beet is one of the better choices for the production of sugar that it contains enough amounts (16 - 20\%) of sucrose over than in sugarcane. In addition to the intended product, sugar beet sucrose gives by products like sugar beet pulp, and molasses that plays a vital role in filling energy gap, especially as an excellent alternative resource of green energy, (Duraisam et al., 2017).

Sugar beet (Beta vulgaris L.) is one of the most important crops in Egypt. Sugar beet yield and quality are dramatically influenced by the level of available $\mathrm{N}$. Residual and fertilizer $\mathrm{N}$ levels allowing adequate top growth and maximize root growth and extractable sucrose concentration are desired. However, sucrose yield decreases by over-fertilizing sugar beet with more $\mathrm{N}$ than needed for maximum sucrose production (Hassanin and Elayan, 2000). An adequate supply of $\mathrm{N}$ is essential for optimum yield but excess $\mathrm{N}$ may result in an increase in yield of roots with lower sucrose content and juice purity. Yield increased with $\mathrm{N}$ applied but TSS, sucrose (\%) and purity (\%) were significantly decreased as N level increased (Lauer, 1995; Badawi et al., 1996; Salama \& Badawi, 1996 and El-Hennawy et al., 1998). The dramatic increase of the used fertilizers requires more attention from producers to reduce the environmental pollution and production cost. This reduction can be obtained by selecting the proper applied fertilizer level that is suitable for the soil and plant species as well as the beneficial application doses to obtain a real increase in the crop yield, and quality and in turn, thus has a high economic return.

Nitrogen is a vital element for sugar beet growth. It is provided through the mineralization of organic matter derived from soil and crop residues, as well as by addition of mineral fertilizers and organic manures (Michel and Rémy 2006). The contents of phosphorous and potassium of beet plant were also significantly positively correlated with nitrogen amount used and nitrogen has obvious interaction effect with phosphorus and potassium. Sugar beet concentrations are decreased and amino nitrogen concentrations increased when crops take up large quantities of nitrogen from soil (Draycott and Christenson, 2003). Application of compost and nitrogen treatments alone showed significant differences in sugar beet root fresh and dry weights compared to that of the control in first season which showed increase growth parameters compared to 
the control and other treatments (Marajan et al., 2017). Soil fertility and crop productivity increased significantly due to nitrogen application (Habtegebial $e t$ al., 2007). Nitrogen fertilization can improve leaf area, leaf area index, photosynthetic rate and eventually high yield, (Cai and Ge, 2004).

Application of $100 \mathrm{~kg} \mathrm{~N} \mathrm{ha}^{-1}$ can result in higher beet and sugar yield (Khan, 2003). Higher economic yield can be obtained with the application of $\mathrm{N}$ levels at the rate of $100 \mathrm{~kg} \mathrm{ha}^{-1}$ (Oad et al., 2008). Among organic fertilizers farmyard manure is the most important, because it contains all macro and micro nutrients required for plant growth but in small amount. Farmyard manure increased the sugar yield by $10 \%$ when applied at the rate of 20 tones $\mathrm{ha}^{-1}$ (Javaheri et al., 2005). In wheat sugar beet rotation addition of farmyard manure at the rate of $30 \mathrm{t} \mathrm{ha}^{-1}$, increase the sugar yield $\left(5.41{\mathrm{t} . h a^{-1}}^{2}\right.$, decreased the soil bulk density of $0-20 \mathrm{~cm}$ depth from 1.46 to $1.38 \mathrm{~g} \mathrm{~cm}^{-3}$ and increased the organic carbon from 0.81 to $0.94 \%$ (Talenghani et al., 2006). Higher sugar production of 7.9 tons $\mathrm{ha}^{-1}$ was obtained with the application of 22.4 tons farmyard manure and $112 \mathrm{~kg} \mathrm{~N} \mathrm{ha}^{-1}$ (Halvorson and Hortman, 1975).

Sugar beet genotype Serenada treated with NP at ratio 120: $90 \mathrm{Kg} \mathrm{ha}^{-1}$ showed improving in sugar beet productivity and quality; therefore it is recommended for general practice in agro-climatic conditions of Peshawar valley (Ahmed et al., 2016).

Horn and Fürstenfeld (2001) showed that the uptake of $\mathrm{N}$ by sugar beet plants increased by increasing the application level of $\mathrm{N}$, while the sugar content and juice purity decreased. $\mathrm{N}$ fertilizer at a level of $285 \mathrm{~kg} \mathrm{~N} / \mathrm{fed}$ accompanied with $114 \mathrm{~kg} \mathrm{~K}_{2} \mathrm{O} \mathrm{ha}^{-1}$ were the most effective in improving yield, quality and nutritional status of sugar beet grown in a sandy calcareous soil (Abdel-Motagally and Attia, 2009). Sugar beet grown under saline conditions showed a change in the chemical composition of leaves and roots. Since saline water has been proposed as an alternative irrigation source for sugar beet, attention should be focused on its positive and negative effects on quality and quantity of sugar beet (El-Wakeel, 1993 and Kaffka et al., 1999).

The aim of the present study was to determine the effect of organic manure and mineral $\mathrm{N}$ fertilization on growth of root yield and quality as well as nutrient content of sugar beet cultivars grown in a sandy calcareous soil.

\section{MATERIALS AND METHODS}

Field experiment was conducted at El-Fajal Farm, El-Tour, South Sinai Governorate during two successive seasons: $2018 / 2019$ and 2019/2020 to study the effect of three levels of farmyard manure $\left(0,10\right.$ and $\left.20 \mathrm{~m}^{3} \mathrm{ha}^{-1}\right)$ and two levels of $\mathrm{N}$ fertilizer (142 and $285 \mathrm{~kg} \mathrm{~N} \mathrm{ha}^{-1}$ ) on the growth, yield, quality and nutrient contents of four sugar beet cultivars (Casiopia $T_{1}$, Salama $T_{2}$, Sahar $T_{3}$ and Faten $\mathrm{T}_{4}$ ) grown in a sandy calcareous soil. Some physical and chemical properties of the used soil before cultivation and after harvesting plants were determined according to Jackson (1958), Table (1). The recommended dose of phosphorus fertilizer was applied at a level $476 \mathrm{~kg}$ superphosphate $\mathrm{ha}^{-1}\left(15.5 \% \mathrm{P}_{2} \mathrm{O}_{5}\right)$ as well as farmyard manure (10 and $20 \mathrm{~m}^{3} \mathrm{ha}^{-1}$ ) during level preparation. A split- split plot design with three replications was used. The main plots were assigned to three levels of Farmyard manure compost and two nitrogen levels of fertilizer which were arranged at sup plots. The area of each plot was $10.5 \mathrm{~m}^{2}$ (3.5 m length $\mathrm{x}$ $3 \mathrm{~m}$ width), with six ridges. Sowing took place on the $2^{\text {nd }}$ and the $5^{\text {th }}$ of November 2018 and 2019, respectively. Seeds were sown in hills $25 \mathrm{~cm}$ apart using 3-4 seeds per hill. Plants were thinned to one plant per hill after 40 days from planting date (at 4-6 leaf stage).

Nitrogen fertilizer in the form of ammonium sulphate $(20.5 \% \mathrm{~N})$ was added in two equal doses. The first one was applied after thinning and the second one 21 days later. Potassium fertilizer in the form of potassium sulphate $\left(48 \% \mathrm{~K}_{2} \mathrm{O}\right)$ was applied in one dose after thinning. The cultural practices were carried out as recommended. At maturity stage (195 days from sowing), plants in $1 \mathrm{~m}^{2}$ were taken at random from each plot. The foliage and roots were separated, washed with water then by distilled water then dried at $70^{\circ} \mathrm{C}$ for 3 days and at $105^{\circ} \mathrm{C}$ for $2 \mathrm{~h}$ in air forced-draft oven, to determine their dry weight. Dry plant samples were ground and chemically analyzed for nutrient content. Total $\mathrm{N}$ was determined by semi-micro Kjeldahl (Jackson, 1958). Phosphorus and $\mathrm{K}$ were determined in the solution from grown plant wet digested in a 2:1 nitric: per-chloric acid mixture and were determined by colorimeter and flame photometry, respectively (Jackson, 1958).

Fresh roots were extracted to determine the following characters: sucrose percentage was determined by using Sacharometer (Le-Docte,1977). Nitrogen use efficiency in sugar beet production systems is the mass of Sucrose produced per $\mathrm{kg}$ of $\mathrm{N}$ supply NUE $=\mathrm{kg}$ sucrose $/ \mathrm{kg} \mathrm{N}$. 
Table 1. Some physical and chemical properties of a representative soil samples in the experimental site before sowing as mean for two seasons $(0-30 \mathrm{~cm}$ depth)

\begin{tabular}{|c|c|}
\hline Soil properties & Values \\
\hline Clay & 3.9 \\
\hline Silt & 8.6 \\
\hline Sand & 87.5 \\
\hline Texture Grade & Sandy \\
\hline PH (Ext. 1:1) & 7.41 \\
\hline $\mathrm{EC}($ Ext. $1: 1), \mathrm{dS} \mathrm{m}^{-1}$ & 2.39 \\
\hline Total $\mathrm{CaCO}_{3}(\%)$ & 33.5 \\
\hline Total Organic Carbon (\%) & 0.264 \\
\hline Total Organic Matter (\%) & 0.428 \\
\hline Nitrogen $\left(\mathrm{mg} \mathrm{kg}^{-1}\right)$ & 17.5 \\
\hline Phosphorus (mg kg-1) & 1.60 \\
\hline Potassium $\left(\mathrm{mg} \mathrm{kg}^{-1}\right)$ & 47.1 \\
\hline \multicolumn{2}{|c|}{ Organic Manure Analysis } \\
\hline PH(Ext.1:1) & 6.80 \\
\hline $\mathrm{EC}\left(\right.$ Ext.1:1), dS m${ }^{-1}$ & 3.15 \\
\hline Total Organic Carbon (\%) & 4.95 \\
\hline Total Organic Matter (\%) & 8.62 \\
\hline Aminouim Nitrogen $\left(\mathrm{mg} \mathrm{kg}^{-1}\right)$ & 269 \\
\hline Nitrare Nitrogen $\left(\mathrm{mg} \mathrm{kg}^{-1}\right)$ & 491 \\
\hline Phosphorus $\left(\mathrm{mg} \mathrm{kg}^{-1}\right)$ & 15.5 \\
\hline Potassium ( $\mathrm{mg} \mathrm{kg}^{-1}$ ) & 164 \\
\hline \multicolumn{2}{|c|}{ Irrigation Water Analysis } \\
\hline $\mathrm{PH}$ & 6.80 \\
\hline $\mathrm{EC}\left(\mathrm{dS} \mathrm{m}{ }^{-1}\right)$ & 3.73 \\
\hline Aminouim $\mathrm{N}\left(\mathrm{mg} \mathrm{L}^{-1}\right)$ & 5.60 \\
\hline Nitrare $N\left(\mathrm{mg} \mathrm{L}^{-1}\right)$ & 22.9 \\
\hline Phosphorus $\left(\mathrm{mg} \mathrm{L}^{-1}\right)$ & 0.11 \\
\hline Potassium $\left(\mathrm{mg} \mathrm{L}^{-1}\right)$ & 0.71 \\
\hline
\end{tabular}

The purity percentage of sugar was calculated from the data of brix and sugar percentage by using the following formula: purity $(\%)=($ Sugar $\% /$ Brix reading $) \times 100$. To compare treatment means; LSD at $5 \%$ level of significance was used according to Steel and Torrie (1980). All statistical analysis was performed by using analysis of variance technique of (Mstat-C) Computer software package. Statistical analysis of variance of split - split plot design according to the procedures outlined by Snedecor and Chochran (1967).

\section{RESULTS AND DISCUSSION}

\section{Effect of organic and mineral nitrogen fertilization on yield of sugar beet cultivars}

Table (2) showed that increasing application of organic fertilizers significantly increased the yield of both roots and foliage. The increases of fresh roots reached to about 39.3 and $77.1 \%$ by addition of 10 and
$20 \mathrm{~m}^{3} \mathrm{ha}^{-1}$ at the mean studied two seasons, respectively. While the dry bulbs recorded 39.2 and $79.0 \%$, respectively. Also, such increases for top fresh yield (foliage) were 95.3, 179.0\% for fresh and 95.1 \& 178.7 $\%$ for dry, respectively. These results agreed with the obtained by Ayaz (2005) and Javaheri et al., (2005).

With respect to the effect of types on the yield of sugar beet, results showed no significant effect on the yield of dry roots but the contrast was clear for fresh bulbs and fresh \& dry top weight where significant increases were observed. The maximum increase of fresh roots reached to $7.1 \%$ for Faten relative to Salama variety. The corresponding increases for sugar beet top fresh and dry weight were 28.0 and $41.7 \%$ for Faten relative to Casupia variety, respectively. The increase of the yield with types is in agreement with the finding of Ahmed et al., (2016) and Ayaz (2005). The differences in yield among the studied genotypes could be due to 
the genetic make of sugar beet cultivars and genetically determined differences in nutrients uptake.

With regard to the effect of $\mathrm{N}$ fertilizer on the yield of sugar beet plants, Table (2 and 3) showed that increasing application of $\mathrm{N}$ fertilizer significantly increased the yield of both roots and foliage. The increases of fresh and dry roots reached to about 14.4 and $16.0 \%$ by the addition of $285 \mathrm{~kg} \mathrm{~N} \mathrm{ha}{ }^{-1}$, respectively. The corresponding increase in foliage yield was 27.9 and $27.9 \%$, respectively. Foliage's of sugar beet are considered a good feed source for livestock. Pectin is also produced from the pulp of sugar beet (Shalaby et al., 2002). These results appear mainly due to the role of $\mathrm{N}$ in developing root dimensions by increasing cell division and/or elongation. The positive effect of $\mathrm{N}$ fertilizer might be due to the increased efficiency of $\mathrm{N}$-fertilization in building up metabolites translocations from leaves to developing roots, thus increases dry matter accumulation (El-Shahawy et al., 2002).

The increase of root and foliage yield with $\mathrm{N}$ fertilizer may be attributed to increased size and number of leaves, which led to increasing leaf area and photosynthetic activities. This was reflected in greater root and sugar production per unit area (Zalat \& Youssif, 2001; El-Kholy et al., 2006 and Malnou et al., 2008).

With respect to the double interactions, results showed a significant effect on the sugar beet yield.

For the interaction of organic fertilization and cultivars of sugar beet, it is noticed that organic fertilization on Salama type $(\mathrm{C} 3+\mathrm{T} 2)$ revealed the highest yield of fresh and dry roots indicating an increase by about 96.4 and $96.6 \%$ relative to $\mathrm{C} 1+\mathrm{T} 2$ treatment, respectively. While the highest rate of organic fertilization and Faten type $(\mathrm{C} 3+\mathrm{T} 4)$ showed the highest fresh and dry yield of the foliage, indicating an increase by about 209 and $214 \%$ over $\mathrm{C} 1+\mathrm{T} 2$ treatment, respectively.

Regarding the interaction of organic and $\mathrm{N}$ fertilizer, results indicated significant effect on all yield of sugar beet. The combined treatment organic with nitrogen fertilizers $(\mathrm{C} 3+\mathrm{N} 2)$ showed the highest yield of roots and foliage and indicated increase of about 100 and $271 \%$ for fresh, and $106 \& 249 \%$ for dry weights relative to $\mathrm{C} 1+\mathrm{N} 1$ treatment, respectively. Similar results are obtained by Zalat and Youssif (2001), Ahmed et al. (2016) and Marajan et al., (2017).

Respecting to the interaction effect of nitrogen and sugar beet cultivars, data showed a significant effect on fresh and dry bulbs and foliage yields. The heights yields were obtained when Faten variety treated with higher rate of $\mathrm{N}$ fertilizer. Such increase reached to 17.5 and $17.5 \%$ for fresh and dry bulbs, 48.3 and $69.3 \%$ for fresh and dry foliage, relative to Casupia $+\mathrm{N} 1$ treatment, respectively.

With respect to the triple interaction, results showed a significant effect on the yields. The highest fresh and dry bulbs were obtained when Salama variety treated with C3 + N2. Such increase reached 121 and $144 \%$ relative to $\mathrm{T} 2+\mathrm{C} 3+\mathrm{N} 2$, respectively. While Faten variety showed highest yield of foliage when treated with C3+N2. These increases reached 347 and 393\% for fresh and dry foliage yield relative to $\mathrm{T} 1+\mathrm{C} 1+\mathrm{N} 1$ treatment, respectively. Similar results were obtained by Sharief \& Eghbal (1994), Abdel-Motagally and Attia (2009), Ahmed et al., (2016) and Ayaz (2005). 
Table 2. Effect of organic manure and mineral nitrogen fertilizer rates on fresh weight of sugar beet cultivars (mean of two seasons)

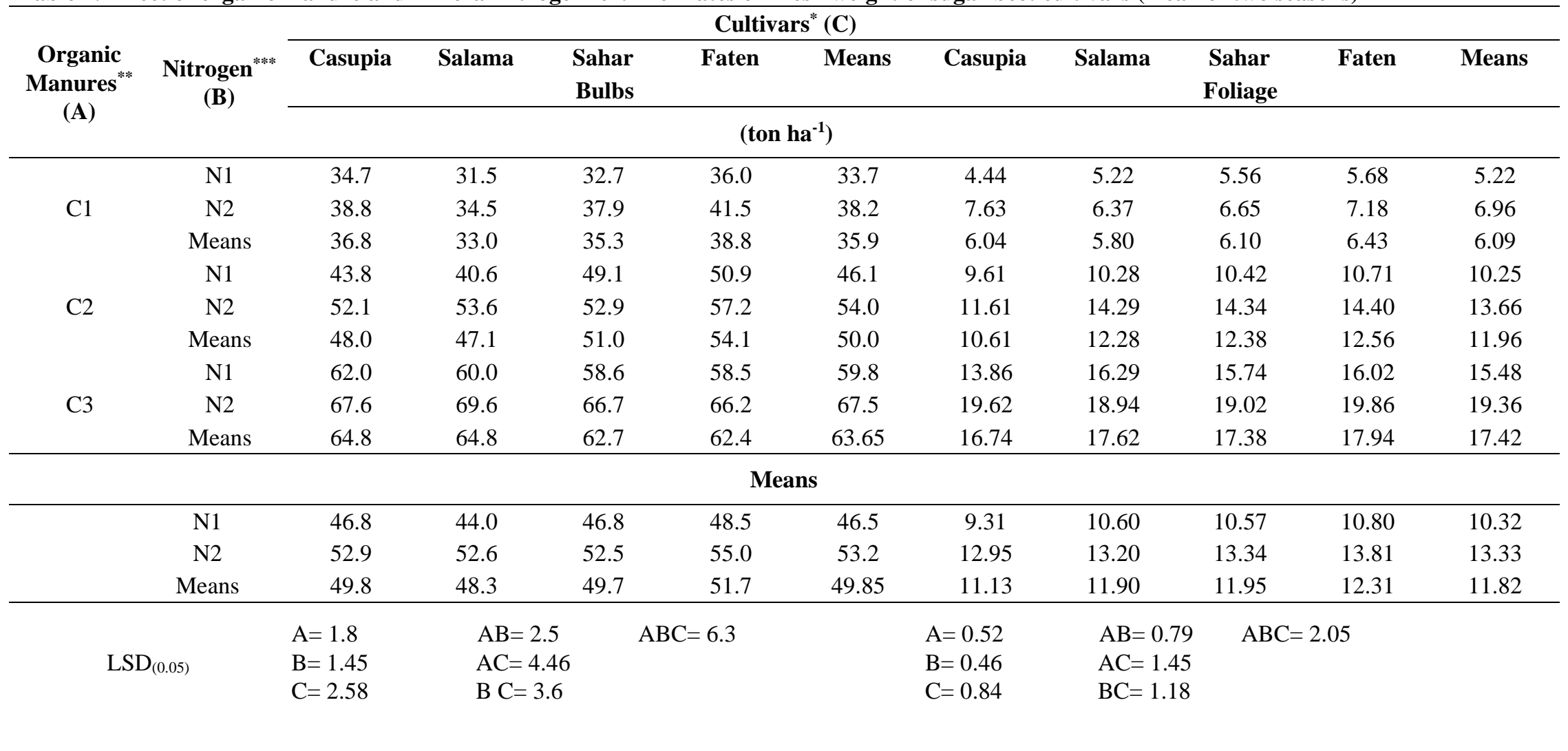

*Cultivars@T1: Casupia T2: Salama T3: Sahar $\quad$ T4: Faten

**Organic manure (A) $\left(\mathrm{m}^{3} \mathrm{ha}^{-1}\right) \ldots \mathrm{C} 1: 0 \ldots \mathrm{C} 2: 10 \ldots \mathrm{C} 3: 20$

****Nitrogen (B) (as. $20.5 \% \mathrm{~N}) \quad \mathrm{N} 1: 142 \quad \mathrm{~N} 2: 285\left(\mathrm{~kg} \mathrm{~N} \mathrm{ha}^{-1}\right)$ 
Table 3. Effect of organic manure and mineral nitrogen fertilization rates on dry weight of sugar beet cultivars (mean of two seasons)

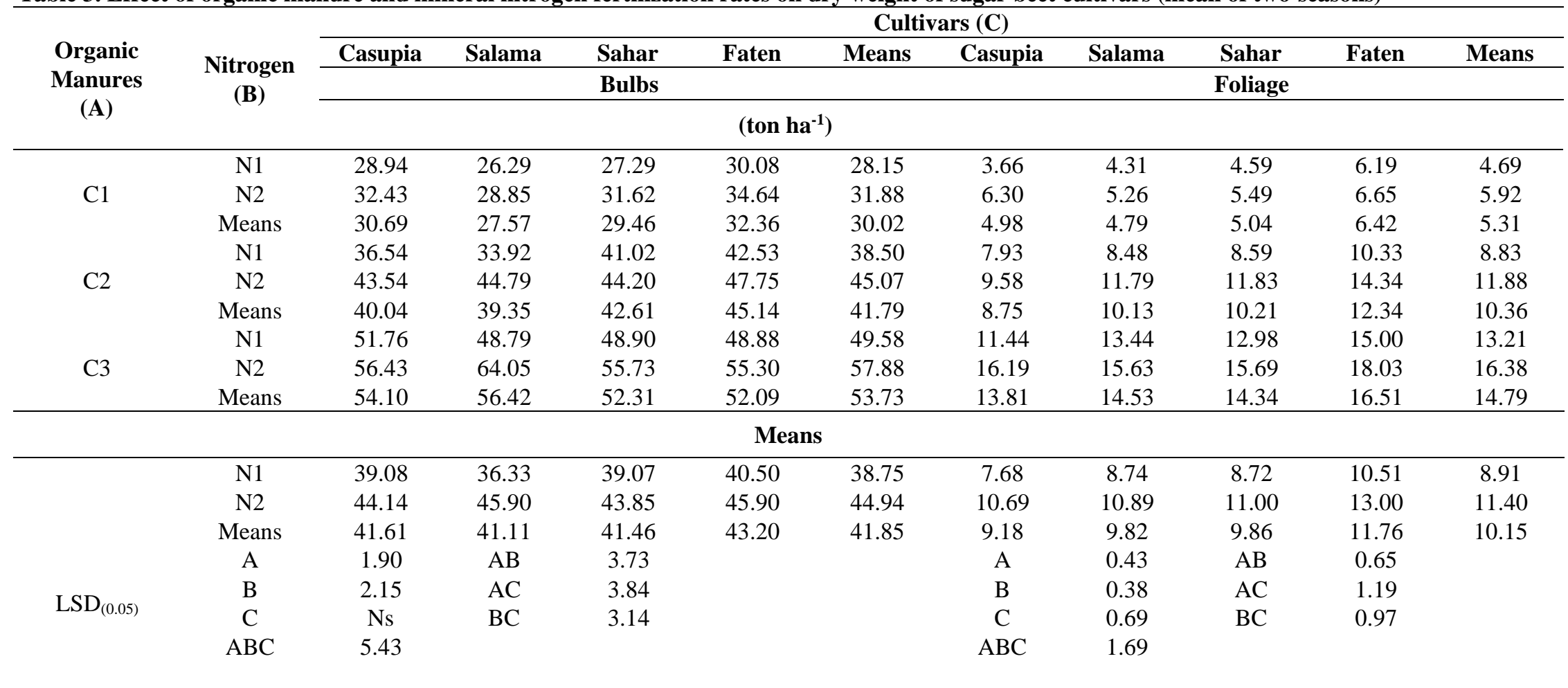

*Cultivars@T1: Casupia T2: Salama T3: Sahar T4: Faten

A: Organic manure $\left(\mathrm{m}^{3} \mathrm{ha}^{-1}\right) \ldots \mathrm{C} 1: 0 \ldots \mathrm{C} 2: 10 \ldots \mathrm{C} 3: 20$

B: Nitrogen (as. $20.5 \% \mathrm{~N}) \quad \mathrm{N} 1: 142 \quad \mathrm{~N} 2: 285\left(\mathrm{~kg} \mathrm{~N} \mathrm{ha}^{-1}\right)$ 
Table 4. Effect of organic manure and mineral nitrogen fertilization rates on some quality parameter roots of sugar beet cultivars (mean of two seasons)

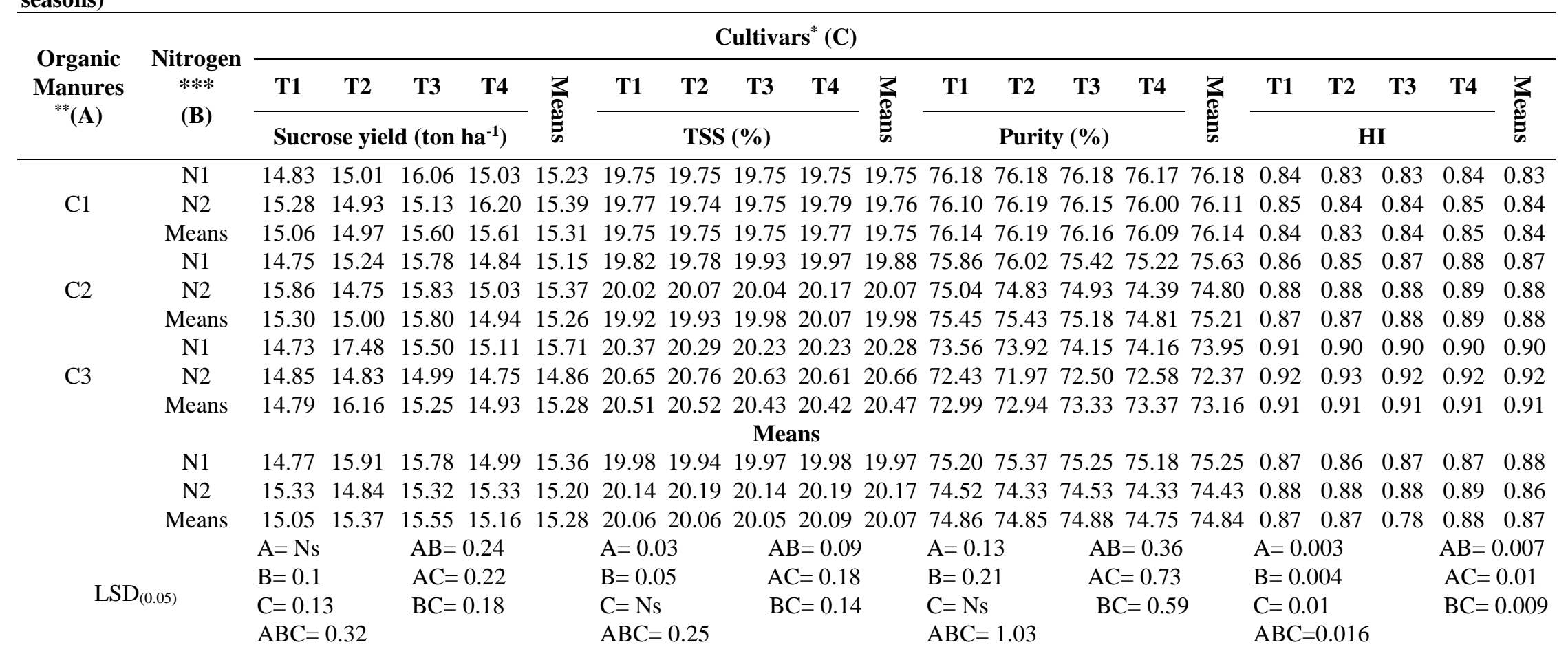

\footnotetext{
*Cultivars(C)T1: Casupia $\quad$ T2:Salama T3:Sahar $\quad$ T4:Faten

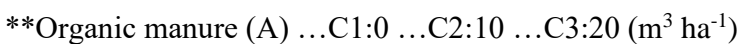

***Nitrogen (B) (as. $20.5 \% \mathrm{~N}) \quad \mathrm{N} 1: 142 \quad \mathrm{~N} 2: 285\left(\mathrm{~kg} \mathrm{~N} \mathrm{ha}^{-1}\right)$
} 
Effect of organic and mineral nitrogen fertilizers on some quality parameters of sugar beet cultivars:

\section{Sucrose:}

Regarding to the effect of organic fertilizers on the sucrose concentrate in roots results in Fig. (1) showed that increasing application of organic fertilizer decreased the sucrose (\%) by about 6.71 and $12.7 \%$ at addition of 10 and $20 \mathrm{~m}^{3} \mathrm{ha}^{-1}$, relative to concentration at no organic addition, respectively. Also, data showed that increasing application of $\mathrm{N}$ fertilizer significantly increased the sucrose by about $3.85 \%$ at addition of 285 $\mathrm{kg} \mathrm{N} \mathrm{ha-1}$, relative to adding lower rate of $\mathrm{N}$. The sucrose concentrates in roots increased by increasing both organic and $\mathrm{N}$ rates especially to Faten variety. The sucrose yield (Table 4) reached its maximum (17.5 ton/ ha) when Salama variety fertilized by highest rate of organic manure and lower rate of $\mathrm{N}$ fertilizer. Such treatment increase the sucrose yield by about $16.5 \%$ relative to the yield of the same variety which fertilized by $\mathrm{C} 3+\mathrm{N} 1$.

Respecting to the TSS\% parameter, Table (4) indicated that increasing addition of both organic and /or $\mathrm{N}$ fertilizers significantly increase the TSS\%. Maximum value $(20.76 \%)$ obtained at Salama variety treated with $\mathrm{C} 3+\mathrm{N} 2$.

Effect of organic and mineral nitrogen fertilizer on nitrogen,_phosphorus and potassium uptake by sugar beet cultivars:

Tables (5 and 6) showed that increasing application of organic fertilizers significantly increased the $\mathrm{N}, \mathrm{P}$ and $\mathrm{K}$ uptake of both roots and foliage. The increases of uptake by roots reached to about $66 \& 157$ for N, $56.3 \&$ 96.2 for $\mathrm{P}$ and $64.4 \& 199 \%$ for $\mathrm{K}$, by adding 10 and 20 $\mathrm{m}^{3} \mathrm{ha}^{-1}$, respectively. The corresponding increases of uptake by sugar beet foliage were $158 \& 324$ for N, 118 \& 205 for P and 158 \& $398 \%$ for K, relative to values of no adding organic, respectively.

With respect to the effect of types on the N, P and K uptake of bulbs and foliage of sugar beet, results showed significant effect on all of them. The increases of $\mathrm{N}$ uptake reached about 13.2, 10.4 and $6.81 \%$ for roots, and 25.2, 61.0 and $29.8 \%$ for foliage, for cultivars $\mathrm{T} 1, \mathrm{~T} 2$ and $\mathrm{T} 4$, respectively compared with $\mathrm{T} 3$ variety.

Also, such increases of $\mathrm{P}$ reached about 2.62, 8.29 and $5.24 \%$ for roots, at cultivars $\mathrm{T} 1, \mathrm{~T} 2$ and $\mathrm{T} 3$, respectively compared with $\mathrm{T} 4$, and $15.0,10.9 \& 21.1 \%$ for foliage at cultivars $\mathrm{T} 2, \mathrm{~T} 3$ and $\mathrm{T} 4$, relative to $\mathrm{T} 1$ variety.

These increases of $\mathrm{K}$ reached to about 46.1, 44.1 and $19.0 \%$ for roots, at cultivars T1, T2 and T3, respectively, and 5.91, 2.96 and $3.18 \%$ for cultivars $\mathrm{T} 1$, $\mathrm{T} 3$ and $\mathrm{T} 4$, respectively.

With regard to the effect of $\mathrm{N}$ fertilizer on the $\mathrm{N}, \mathrm{P}$ and $\mathrm{K}$ uptake of sugar beet plants, Table (5 and 6) showed that increasing application of $\mathrm{N}$ fertilizer significantly increased $\mathrm{N}, \mathrm{P}$ and $\mathrm{K}$ uptake by both roots and foliage, reached to about $28.1 \& 43.1$ and $11.6 \&$ 22.3 and $22.8 \& 53.6 \%$, respectively by addition of 285 $\mathrm{kg} \mathrm{N} \mathrm{ha-1}$.Similar results were obtained by Zalat and Youssif (2001) and Ahmed et al., (2016).

With respect to the double interactions, results showed a significant effect on $\mathrm{N}, \mathrm{P}$ and $\mathrm{K}$ uptake of both roots and foliage. For the interaction of organic fertilization and cultivars of sugar beet, it is noticed that $(\mathrm{C} 3+\mathrm{T} 2)$ revealed the highest $\mathrm{N}$ and $\mathrm{P}$ uptake of roots and foliage indicating an increase by about $224 \& 129$ and $320 \& 236 \%$, respectively, relative to $(\mathrm{C} 1+\mathrm{T} 2)$ treatment and the highest $\mathrm{K}$ uptake of roots indicating an increase by about $40 \%$ at the same treatment. While foliage indicating an increase by about $523 \%$ with $(\mathrm{C} 3+$ $\mathrm{T} 3)$ over $(\mathrm{C} 1+\mathrm{T} 3)$.

Regarding the interaction of organic fertilization and $\mathrm{N}$, results indicated significant effects on the $\mathrm{N}, \mathrm{P}$ and $\mathrm{K}$ uptake by roots and foliage of sugar beet. The combined treatment organic with nitrogen fertilizers $(\mathrm{C} 3+\mathrm{N} 2)$ showed the highest $\mathrm{N}, \mathrm{P}$ and $\mathrm{K}$ uptake of both roots and foliage and increases increased to about 223, 112 \& $301 \%$ and $535,257 \& 604 \%$, respectively relative to $\mathrm{C} 1$ $+\mathrm{N} 1$ treatments. 
Table 5. Effect of organic manure and mineral nitrogen fertilization rates on uptake of $N, P$ and $K$ by roots of sugar beet varieties (mean of two seasons)

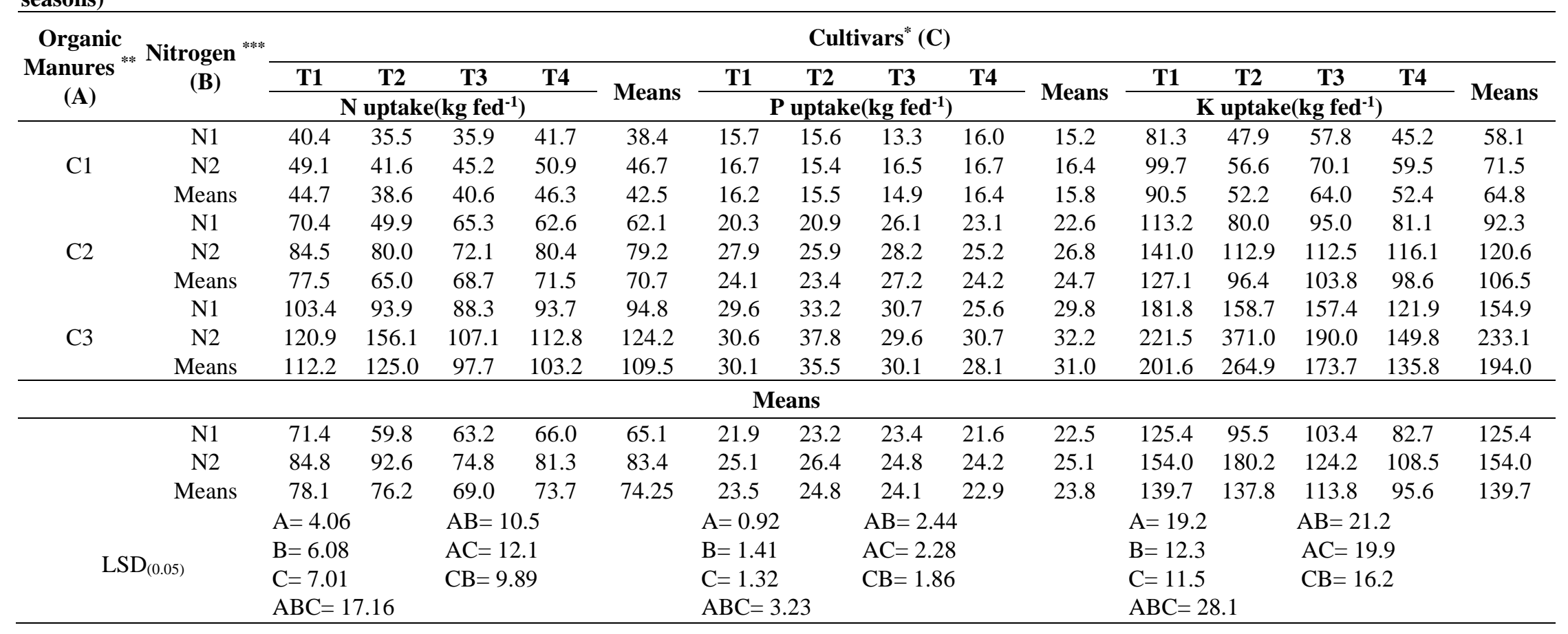

*Cultivars(C)T1: Casupia T2: Salama T3: Sahar T4: Faten

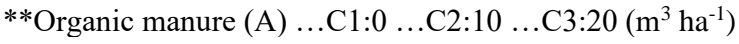

***Nitrogen (B) (as. 20.5\% N) N1: $142 \quad \mathrm{~N} 2: 285\left(\mathrm{~kg} \mathrm{~N} \mathrm{ha}^{-1}\right)$ 
Table 6. Effect of organic manure and mineral nitrogen fertilization rates on uptake of $\mathrm{N}, \mathrm{P}$ and $\mathrm{K}$ by foliage of sugar beet varieties (mean of two seasons)

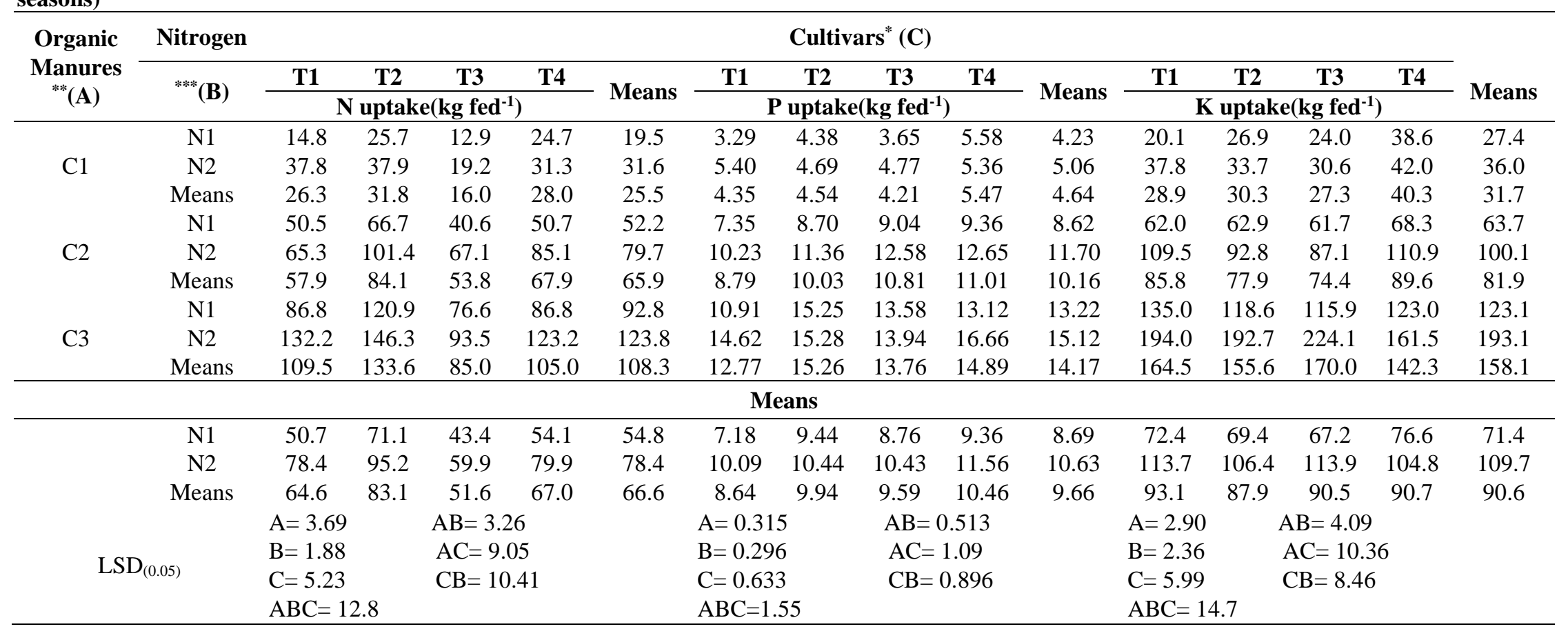

*Cultivars(C)T1: Casupia T2:Salama T3:Sahar T4:Faten

**Organic manure (A)...C1:0 ..C2:10 ..C $3: 20\left(\mathrm{~m}^{3} \mathrm{ha}^{-1}\right)$

***Nitrogen (B) (as 20.5\% N) N1: $142 \quad \mathrm{~N} 2: 285\left(\mathrm{~kg} \mathrm{~N} \mathrm{ha}^{-1}\right)$ 
Table 7. Effect of organic manure and nitrogen fertilization rates on concentration of some elements in roots of sugar beet varieties

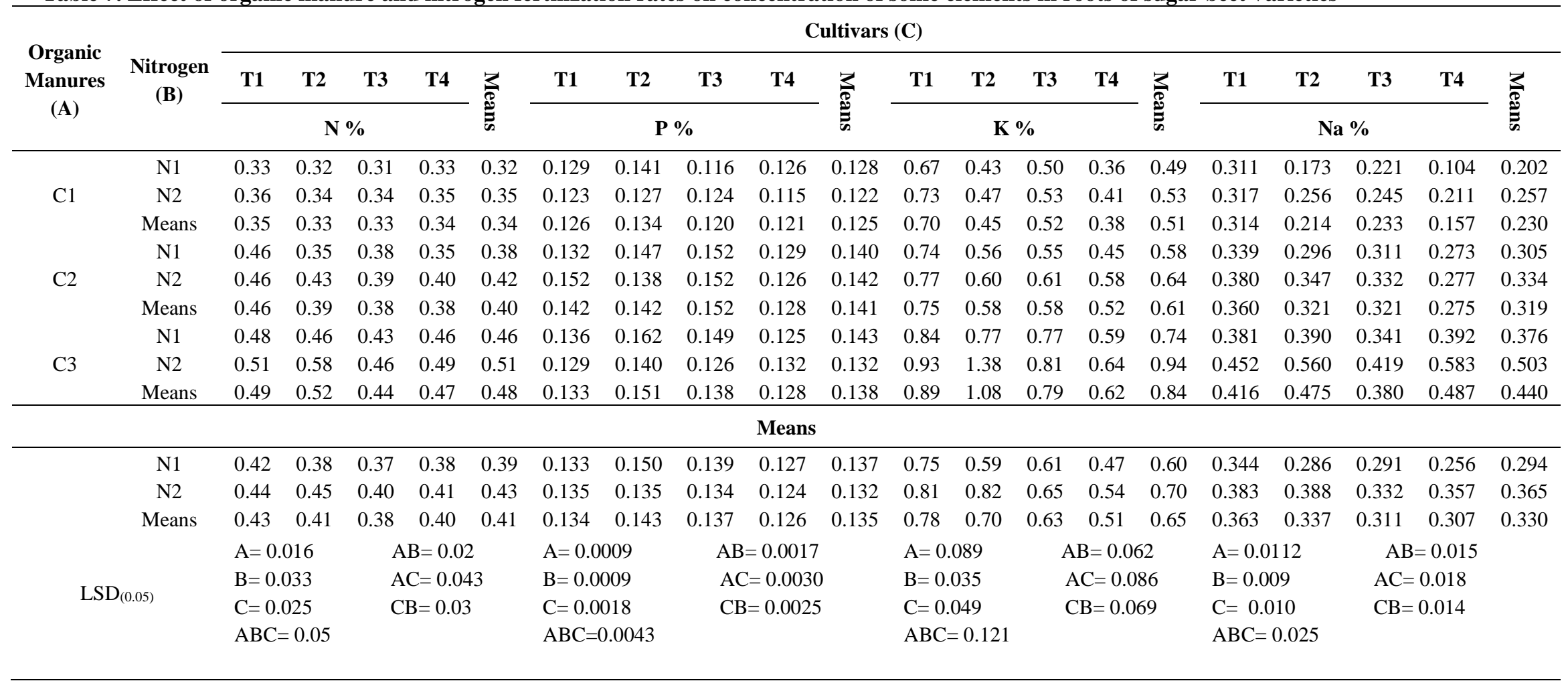

T1: Casupia T2:Salama T3:Sahar T4:Faten

A: Organic manure...C1:0 ...C2:10 ...C3:20 $\left(\mathrm{m}^{3} \mathrm{ha}^{-1}\right)$

B: Nitrogen (as. $20.5 \% \mathrm{~N}) \quad \mathrm{N} 1: 142 \quad \mathrm{~N} 2: 285\left(\mathrm{~kg} \mathrm{~N} \mathrm{ha}^{-1}\right)$ 
Table 8. Effect of organic manure and nitrogen fertilization rates on concentration of some elements in foliage of sugar beet varieties

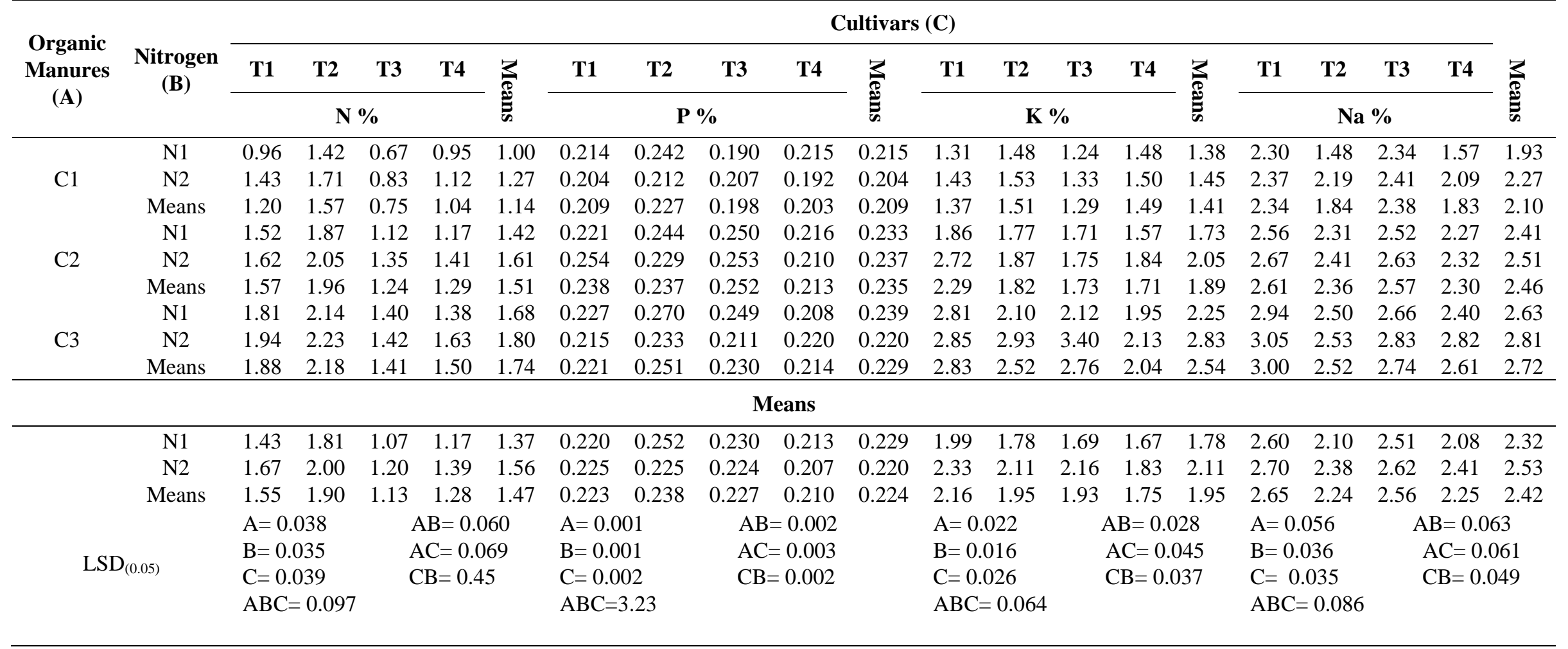

T1: Casupia $\quad$ T2:Salama $\quad$ T3:Sahar $\quad$ T4:Faten

A: Organic manure...C1:0 _..C2:10 ...C3:20 $\left(\mathrm{m}^{3} \mathrm{ha}^{-1}\right)$

B: Nitrogen (as. $20.5 \% \mathrm{~N}) \quad \mathrm{N} 1: 142 \quad \mathrm{~N} 2: 285\left(\mathrm{~kg} \mathrm{~N} \mathrm{ha}^{-1}\right)$ 
Respecting the interaction between cultivars of sugar beet and $\mathrm{N}$, results revealed significant effect on the $\mathrm{N}$, $\mathrm{P}$ and $\mathrm{K}$ uptake of roots and foliage. The combined treatment $(\mathrm{T} 2+\mathrm{N} 2)$ showed the highest $\mathrm{N}, \mathrm{P}$ and $\mathrm{K}$ uptake of roots and foliage giving increases reached to about 54.9, $13.8 \& 88.7$ and33.9, 10.6 \& 53.3\%, respectively over $\mathrm{T} 2+\mathrm{N} 1$ treatment.
With respect to the triple interaction, results showed significant effects on the $\mathrm{N}, \mathrm{P}$ and $\mathrm{K}$ uptake of roots and foliage of sugar beet. So the treatment $(\mathrm{C} 3+\mathrm{N} 2+\mathrm{T} 2)$ showed the highest $\mathrm{N}, \mathrm{P}$ and $\mathrm{K}$ uptake of both roots and foliage as indicated by $340,184 \& 721$ and $1034,364 \&$ $859 \%$, respectively Relative to the lowest values. These results as found by Horn and Fürstenfeld (2001), Ahmed et al., (2016), Oad et al., (2008) and Marajan et al., (2017)

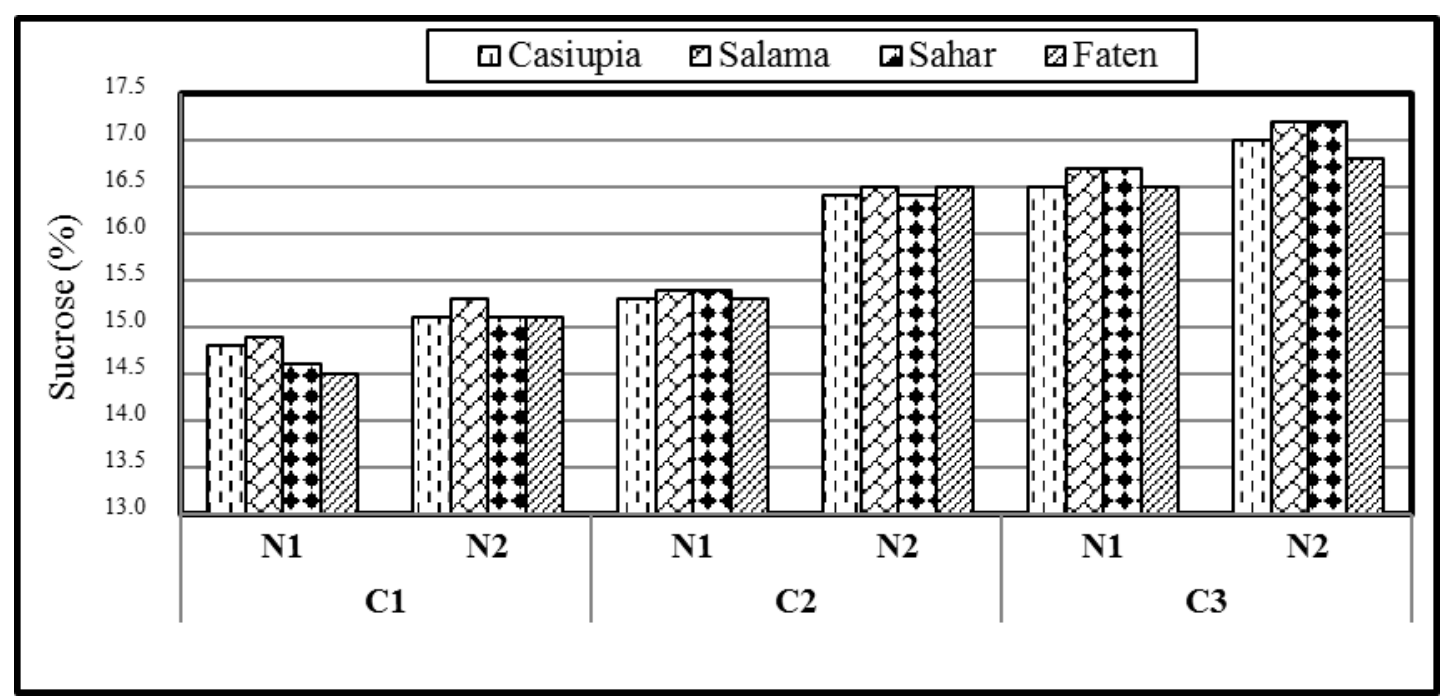

Fig. 1. Effect of interaction between organic manure and nitrogen fertilization rates on sucrose concentration of sugar beet cultivars (mean of two seasons)

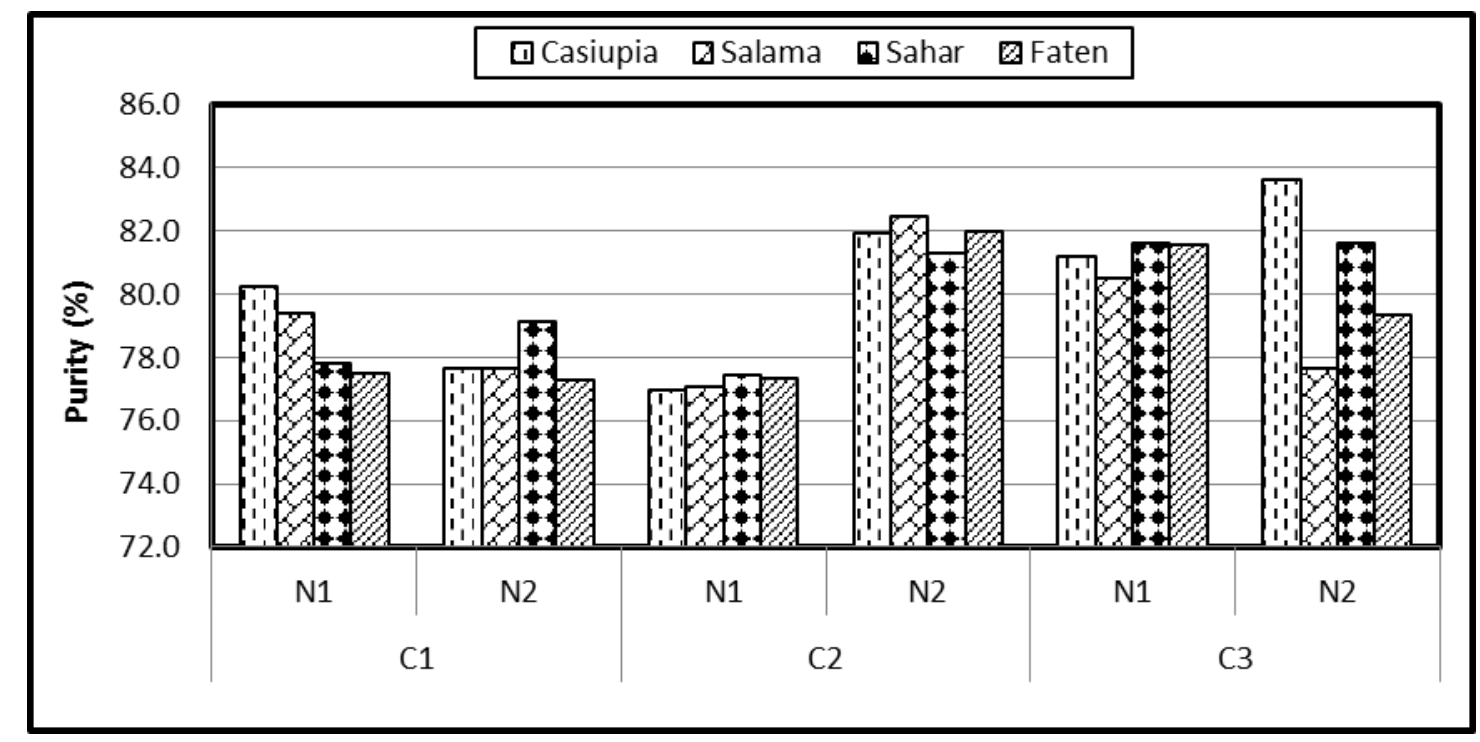

Fig. 2. Effect of interaction between organic manure and nitrogen fertilization rates on purity of sugar in sugar beet cultivars (mean of two seasons) 


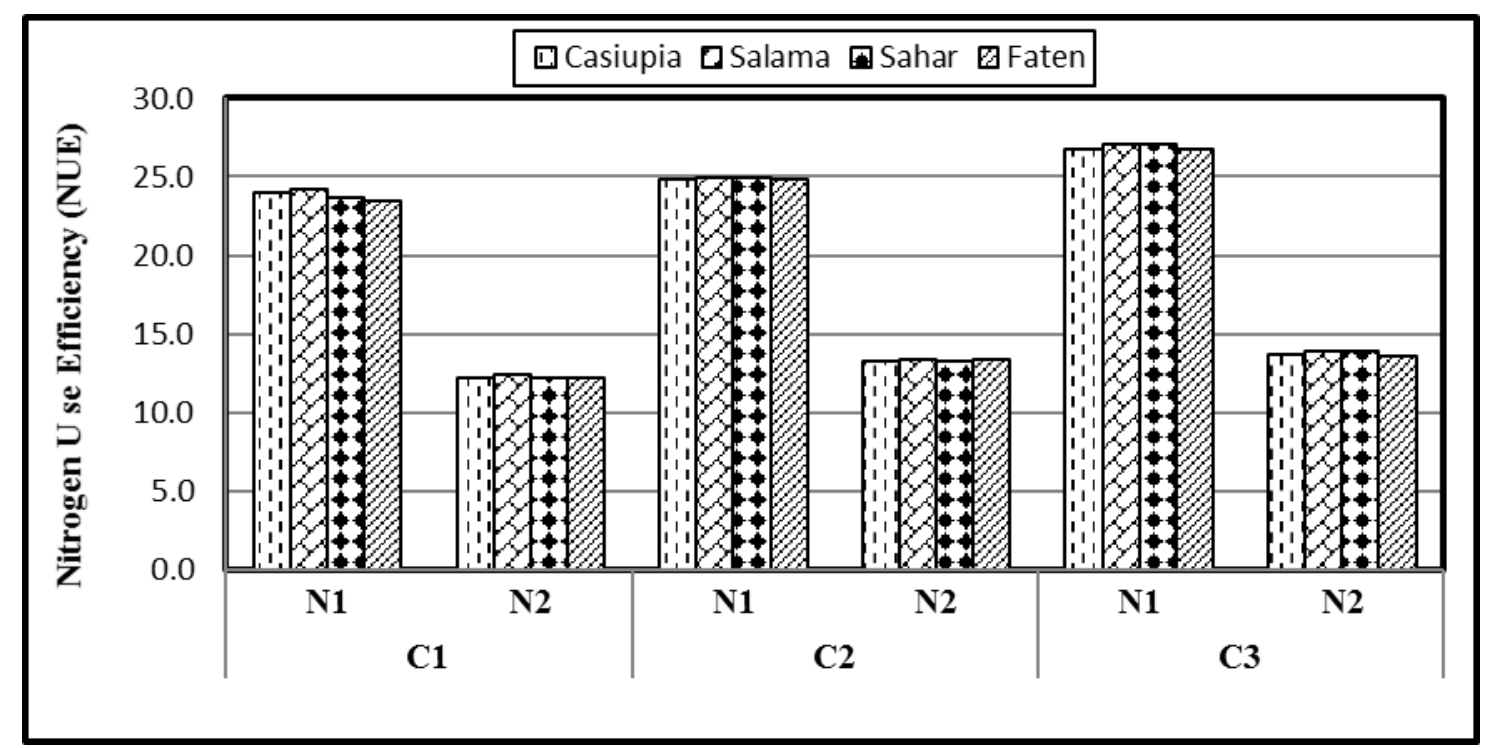

Fig. 3. Effect of interaction between organic manure and nitrogen fertilization rates on nitrogen use efficiency of sugar beet cultivars (mean of two seasons)

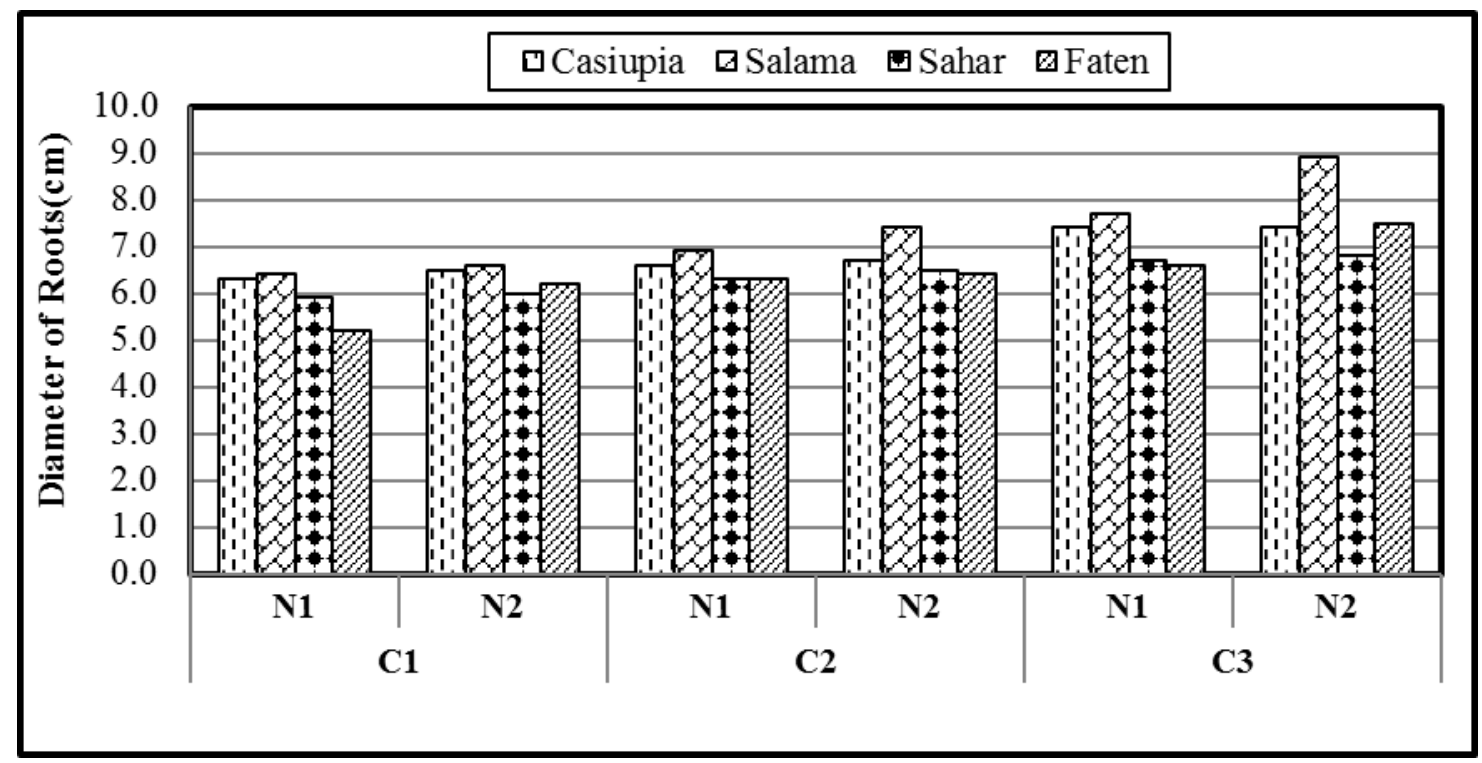

Fig. 4. Effect of interaction between organic manure and nitrogen fertilization rates on diameter of roots of sugar beet cultivars (mean of two seasons) 


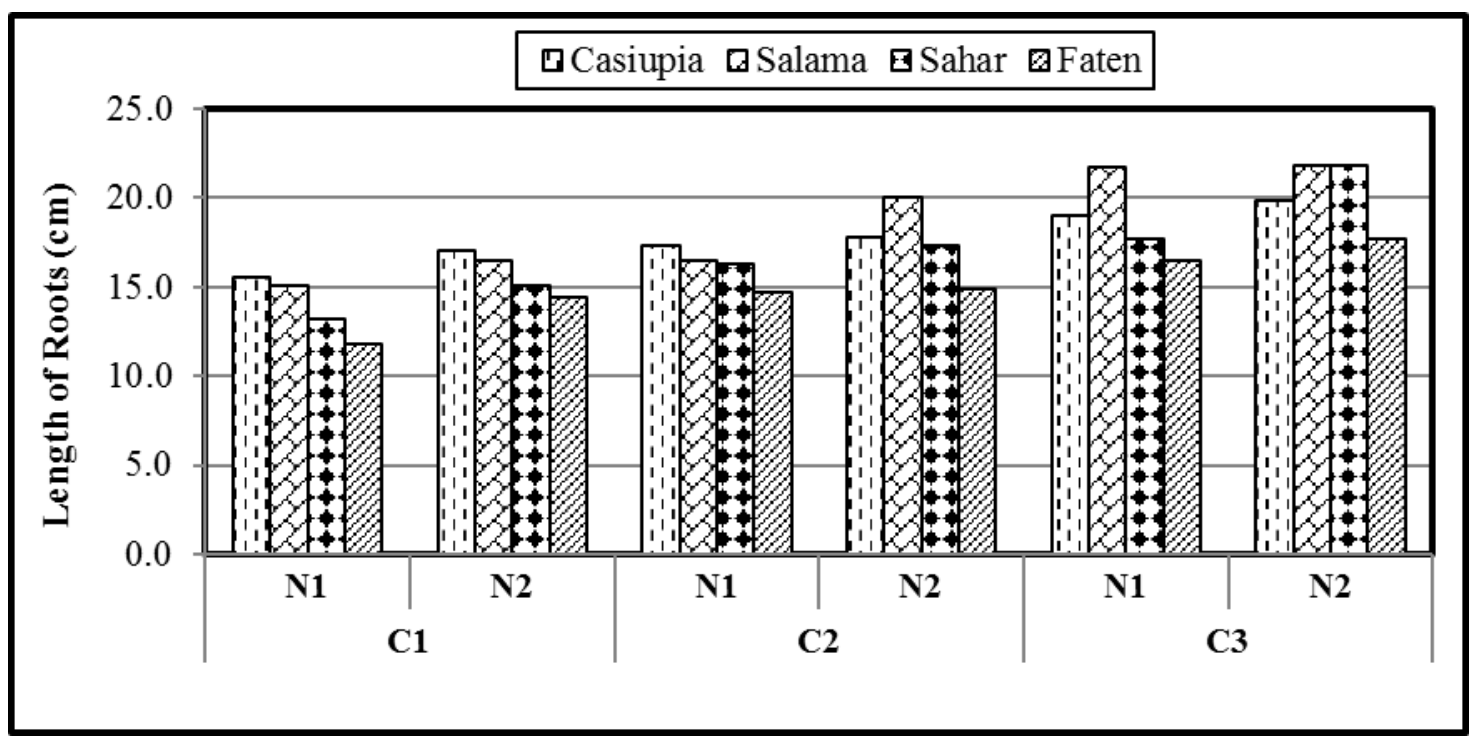

Fig. 5. Effect of interaction between organic manure and nitrogen fertilization rates on length of root on sugar beet cultivars (mean of two seasons)

Effect of organic and mineral nitrogen fertilizers on soil properties after harvesting:

Regarding to the effect of organic fertilizers on the some soil properties results in Tables (9) showed that increasing application of organic fertilizers improves soil fertility as increasing of available N, P and K. So the results showed increase in amount of available $\mathrm{N}, \mathrm{P}$ and $\mathrm{K}$. Increasing application of both organic manure and $\mathrm{N}$ fertilizers increased the available amounts of $\mathrm{N}, \mathrm{P}$ and $\mathrm{K}$ after harvesting all studied sugar beet genotypes.

Table 9. Some physical and chemical properties of soil samples after harvesting (mean of the studied two seasons)

年

\begin{tabular}{|c|c|c|c|c|c|c|c|c|c|c|c|c|c|}
\hline \multicolumn{2}{|c|}{ Control } & 3.86 & 8.64 & 87.5 & Sandy & 2.39 & 7.41 & 33.5 & 0.246 & 0.428 & $1-72.5$ & 1.6 & 47.1 \\
\hline \multirow{2}{*}{$\mathrm{C} 1$} & N1 & 4.58 & 9.88 & 85.5 & Sandy & 2.46 & 7.51 & 29.0 & 0.409 & 0.713 & 15.3 & 5.40 & 49.4 \\
\hline & $\mathrm{N} 2$ & 4.75 & 9.80 & 85.4 & Sandy & 2.57 & 7.55 & 29.1 & 0.434 & 0.755 & 19.7 & 5.90 & 51.7 \\
\hline \multirow{2}{*}{$\mathrm{C} 2$} & N1 & 4.81 & 9.76 & 85.4 & Sandy & 1.97 & 7.12 & 29.1 & 0.567 & 0.986 & 21.1 & 6.22 & 66.9 \\
\hline & $\mathrm{N} 2$ & 4.98 & 9.56 & 85.4 & Sandy & 2.07 & 7.10 & 28.9 & 0.569 & 0.990 & 26.9 & 6.56 & 70.1 \\
\hline \multirow{2}{*}{ C3 } & N1 & 5.50 & 9.52 & 84.9 & Sandy & 1.95 & 7.07 & 28.9 & 0.667 & 1.16 & 31.5 & 7.81 & 81.5 \\
\hline & $\mathrm{N} 2$ & 5.58 & 9.47 & 84.9 & Sandy & 2.15 & 7.05 & 28.7 & 0.672 & 1.17 & 38.6 & 7.95 & 85.6 \\
\hline
\end{tabular}


The increasing organic fertilizers decreased $\mathrm{pH}$ and EC due acidic effect and it's containing of macro and micronutrients which required for plant growth (Oad et al., 2008). Also, the results showed that increases of organic matter and decrease $\mathrm{CaCO}_{3} \%$ with increasing organic manure application, while increasing application of $\mathrm{N}$ lead to a slight effect on both $\mathrm{CaCO}_{3}$ (\%) and organic matter content. Since saline water has been proposed as an alternative irrigation source for sugar beet, attention should be focused on its positive and negative effects on quality and quantity of sugar beet. These results agreed with (El-Wakeel, 1993 and Kaffka et al., 1999). It is provided that through the mineralization of organic matter derived from soil and crop residues, as well as addition of mineral fertilizers and organic manures plays a vital role in sugar beet productivity, (Michel and Rémy 2006).

\section{CONCLUSION}

There were significant effects of the organic and $\mathrm{N}$ fertilization rates on the nutrient uptakes in root and foliage of sugar beet and their highest values were always obtained at the highest organic and $\mathrm{N}$ fertilization rates applied. Moreover, the highest weight at of roots was obtained under addition $20 \mathrm{~m}^{3}$ organic manure and $285 \mathrm{~kg} \mathrm{~N} \mathrm{ha}^{-1}$ using Salama cultivar. From the previous discussion, it can be concluded that it is important to use the suitable amounts of organic fertilizers and the most efficient rate under this study which is $20 \mathrm{~m}^{3} \mathrm{ha}^{-1}$ combined with $285 \mathrm{~kg} \mathrm{~N} /$ fed to give the maximum yield of sugar beet plants under the present study conditions. Also, it is noticed that the Salama type (T2) it the most efficient genotype than the other types.

\section{REFERENCE}

Abdel-Motagally, F.M.F. and K.K. Attia. 2009. Response of Sugar Beet Plants to Nitrogen and Potassium Fertilization in Sandy Calcareous Soil. Int. J. Agric. Biol. 11: 695-700.

Ahmad, I., B.Ahmad, S.Ali, H.Q. Fang, T.Liu, M. Kamran, Y.Wu, M.U.Rahman and S.Faisal. 2016. Organic and Inorganic Fertilization Influenced on Yield and Quality of Sugar Beet Genotypes. Russian Agric. Sci. 42(3-4): 218223.

Ayaz, M.T. 2005. Effect of nitrogen and irrigation on sugar beet production, M. Sc. Thesis., Peshawar: Agric. Univ., Pakistan.

Badawi, M.A., M.A. El-Agroudy and A.N.Attia. 1996. Effect of planting dates and NPK fertilization on growth and yield of sugar beet (Beta vulgaris L.). J. Agric. Sci. Mansoura University. 20: 2683-2689.

Cai, B. and J.Ge. 2004. The effect of nitrogen amount on photosynthetic rate of sugar beet, Nature Sci. 2(2): 6063.

Draycott, A.P. and D.R.Christenson. 2003. Nutrients for Sugar Beet Production: Soil Plant Relationships. CABI Publishing, Wallingford.
Duraisam, R., K. Salelgn and A.K.Berekete. 2017. Production of Beet Sugar and Bio-ethanol from Sugar beet and it Bagasse: A Review. International J. of Engineering Trends and Technology (IJETT). 43: 222-233.

El-Hennawy, H.H., B.S.H. Ramadan and E.A. Mahmoud. 1998. Response of sugar beet to nitrogen fertilization levels and its time of application. J. Agric. Sci. Mansoura Uni. 23: 969-978

El-Kholy, M.H., M.T. Abdelhamid and E.H.H.Selim. 2006. Effect of soil salinity, nitrogen fertilization levels and potassium fertilization forms on growth, yield and quality of sugar beet crop in East northern Delta of Egypt. J. Agric. Sci. Mansoura Univ. 31: 4049-4063

El-Wakeel, A.F. 1993. Effect of some soil characteristic on root growth, juice quality and yield of sugar beet. Egyptian J. of Agric. Res. 71 (3): 609 - 620.

El-Shahawy, M.I., S.A.El-Wahab, M.M. AbdSobh and E.A.E.Nemeatalla. 2002. Productivity and NPK uptake of sugar beet as influenced by N, B and Mn fertilization. $J$. Agric. Sci. Mansoura University. 27: 1955-1964.

FAO. 2012.Annual Statistical Report, Food \& Agriculture Org of the UN (15 April).

Habtegerial, K., B.R.Singh and M.Haile. 2007. Impact of tillage and nitrogen on fertilization on yield, nitrogen use efficiency of tefEragrostis, Trotter and soil properties, Soil Till. Res. 94: 55-63.

Halvorson, A.D. and G.P.Hortman. 1975. Long term nitrogen rates and sources influence sugar beet yield and quality, Agron. J., 67. 3: 389-393.

Horn, D. and F. Fürstenfeld. 2001. Nitrogen fertilizer recommendation for sugar beet according to the EUF soil testing system. In: Plant Nutrition. 92: 746-747.

Jackson, M.L. 1958. Soil Chemical Analysis. Prentice-Hall Inc., Englewood Cliff. New Jersey

Javaheri, M.A., N.Rashid and A.Baghizadeh. 2005. Influence of organic farm yard manure, potassium and boron on quantity and quality of sugar beet in Bardsir region, J. Sugar Beet (Iran). 21:31-41.

Kaffka, S., Dong-Daxue, G.Peterson, and Dx.Dong. 1999. Saline water can be reused irrigate sugar beets but sugar may be low. California Agri. 53: 1. 11 - 15.

Khan, D. 2003. The effect of application methodology and doses of nitrogen and phosphorus on sugar beet husbandry, in Annu. Tech. Rep. S.C.R.I., Mardan. 72-73.

Lauer, J.G. 1995. Plant density and nitrogen rate effects on sugar beet yield and quality early in harvest. Agron. J. 87: 586-591.

Le Docte, A. 1977. Commercial determination of sugar in sugar beet using the socks sugar J. 29, 488-492.

Malnou, C.S., K.W. Jaggard and D.L. Sparkes. 2008. Nitrogen fertilizer and the efficiency of the sugar beet crop in late summer. Euro. J. Agron. 28: 47-56.

Marajan, W.A., M.A.Hadad, M.O.Gafer, H.A. Sulfab and M. A.Ali. 2017. Effect of Mineral and Bio-organic Fertilizers on Sugar beet Growth under Semi-Arid Zone. International Journal of Science and Research (IJSR) (Online). 6 (9):1020-1025.

Michel, C. and D.Rémy. 2006.Sugar Beet.Nutrition -Nitrogen. Blackwell Publishing Ltd. 9600 Garsington Road, Oxford OX4 2DQ, UK. www.blackwellpublishing.com. 
Oad, F.C., M.U. Usmanikhail, M.H. Siddique and N.Junejo. 2008. Response of sugar beet (Kaweterma) to different fertility levels, Pak. Sug. J. 23, 2: 5-10.

Salama, A.M. and M.A.Badawi. 1996. Evaluation of six sugar beet cultivars under N-levels and harvesting dates. J. Agric. Sci. Mansoura Univ. 21: 139-153.

Sharief, A.E. and K.Eghbal. 1994. Yield of seven sugar beet varieties under different levels of nitrogen in dry region of Egypt. Agri-biol. Res. 47: 231-241.

Shalaby, M.T., M.B.Doma, F.A. Abd-El-Latief and S.M. ElSadik. 2002.Agricultural, chemical and technological studies of potassium application on yield, chemical constituents and juice quality characteristics of sugar beet. J. Agric. Sci. Mansoura Univ. 27: 7503-7512
Snedecor, G.V. and W.G. Cochran. 1967. Statistical methods 6th Ed Iowa State Univ. Press, Amess, Iowa, USA.

Steel, R.G. and H.H.Torrie. 1980. Principles and procedures of statistics.2Ed. McGraw Hill. New York.

Taleghani, D.F., S.S. Hemayati, H. Noshad, M. Dehaghanshoar, G.Togidloo and F. Hamdi. 2006. Effects of different manuring levels on some quantity and quality factors of sugar beet in wheat-sugar beet rotation, J. Sugar Beet (Iran). 22: 67-68.

Zalat, S.S. and N.O.A. Youssif. 2001. Effect of application time of potassium fertilizer and its ratio with nitrogen on the yield and quality of sugar beet crop (Beta vulgaris L.) Minufia J. Agric. Res. 26: 401-408.

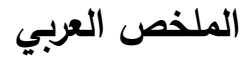

استجابة بعض اصناف بنجر السكر للتسميد العضوى والمعدنى تحت ظروف الاراضى الجيرية الرملية بجنوب

$$
\text { اشرف احمد محمد حبيب - مصر }
$$

و YNo كجم نيتروجين للهكتار أعلى تركيز لعناصر النيتروجين والفوسفور فى الصنف سلامة بينما الصنف فاتن

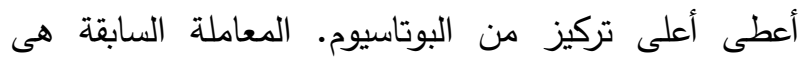
الأفضل فى كمية السكر فى الأصناف المدروسة حيث

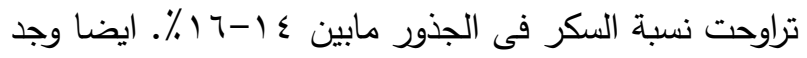
فى تحليل التربة بعد إنتهاء التجربة أن المعاملات السمادية كائ من السماد العضوى والنيتروجينى خفض من قلوية التربة وكنلك زيادة تركيز بعض العناصر الميسرة فى التربة كالنيتروجين والفوسفور و البوتاسيوم. أيضا أدى التسميد العضوى إلى خفض معدل ترسيب الفوسفور فى مثل هذه

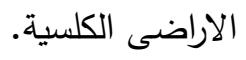

اقيمت تجربة حقلية بمنطقة الطور بمحافظة جنوب سيناء

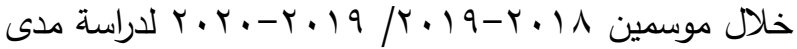
إستجابة بعض اصناف بنجر السكر للتسميد العضوى والمعدنى تحت ظروف الاراضى الجيرية. صمدت التجربة بنظام القطاعات المنشقة مرتين على أن يكون التسميد العضوى العامل الرئيسى والتسميد النيتروجينى المعدنى هو العامل الفرعى والاصناف هى تحت الفرعى. أشارت النتائج إلى زيادة الإنتاجية لكل من الجذور والاوراق من الفدان بزيادة التسميد العضوى والمعدنى فقد

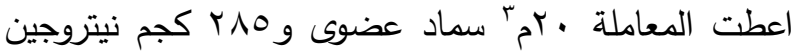
للهكتار اعلى انتاج من الصنف سلامة والذى وصل إلى 9,^ 7 طن جذور للهكتار ، بينما أعلى إنتاج من الاوراق كان للصنف فاتن والتى وصل ^,9 1 طن للهكتار . أما بالنسبة لتركيز العناصر الممتصة داخل الجذور فقد أظهرت المعاملة

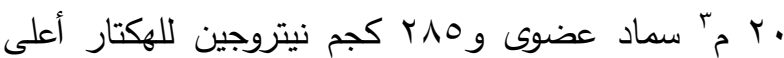
تركيز لعناصر النيتروجين والفوسفور والبوتاسيوم فى جذور الصنف سلامة .بينما تركيز العناصر داخل المجموع الخضرى للنباتات فقد أعطت المعاملة . ب مب سماد عضوى 